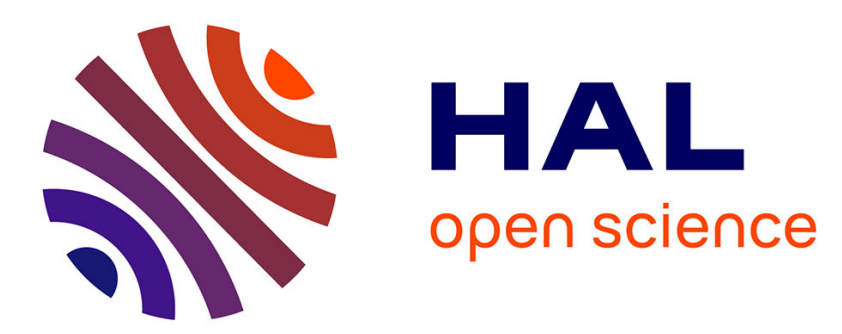

\title{
The Identification of the Professional Profile that Uses Canvas Approach
}

\author{
Irapuan Glória Júnior, Rodrigo Franco Gonçalves
}

\section{To cite this version:}

Irapuan Glória Júnior, Rodrigo Franco Gonçalves. The Identification of the Professional Profile that Uses Canvas Approach. IFIP International Conference on Advances in Production Management Systems (APMS), Sep 2016, Iguassu Falls, Brazil. pp.544-551, 10.1007/978-3-319-51133-7_65 . hal01615778

\section{HAL Id: hal-01615778 \\ https://hal.inria.fr/hal-01615778}

Submitted on 12 Oct 2017

HAL is a multi-disciplinary open access archive for the deposit and dissemination of scientific research documents, whether they are published or not. The documents may come from teaching and research institutions in France or abroad, or from public or private research centers.
L'archive ouverte pluridisciplinaire HAL, est destinée au dépôt et à la diffusion de documents scientifiques de niveau recherche, publiés ou non, émanant des établissements d'enseignement et de recherche français ou étrangers, des laboratoires publics ou privés. 


\title{
The Identification of the Professional Profile that uses Canvas Approach
}

\author{
Irapuan Glória Júnior ${ }^{1,2}$ and Rodrigo Franco Gonçalves ${ }^{1}$ \\ 1 Paulista University, São Paulo, Brazil, \\ 2 Centro Paula Souza, São Paulo, Brazil \\ ijunior@nsdgn. com.br
}

\begin{abstract}
This paper shows the study of the canvas approach to the profiles of team members. It has a qualitative character. The objective is to identification the professional profile that uses the canvas approach. The results relate 12 Canvas Models and its interaction with 6 consulted professional profiles. The main contribution is the identification of relations between the use of the tools and professional profiles. However, the sequence of use idealized by the Canvas creators is not followed by the professional in practice.
\end{abstract}

Keywords: Canvas · Business model canvas · Profile · Project model canvas

\section{Introduction}

The large number of projects that fail is great, often caused by the lack of an adequate approach to development[1]. There are several frameworks available in the market, but have many stages in its development cycle and the creation of various documents[2].

Some professional choose to use a faster alternative with graphical approaches and the use of post-it, called Canvas approach. This concept can help to speed up the process of creation by the development team of a new business[3], a new project[4] or until the creation of a digital game[5].

There are a considerable number of types of Canvas and the initial use in design applications has grown systematically, with several examples in the market and in academy [6]. It is possible to find applications in various types of projects, such as helping of SME[7].

The objective of this paper is to identification the professional profile that uses the "Canvas approach". Thus, can contribution to the evaluation of the companies if the adopt is possible an Canvas approach, can decrease the time learning and to show criterious for to hire members to form the "Canvas Model Team". 


\section{Theoretical Background}

\subsection{Model Canvas}

Canvas has graphical approach, used annotations or post-its and containers to receive the informations[3]. It is used as process register instrument and create the reuse of information from one project to another[6].

The nomenclature of this technique can be found as "Canvas Approach ", "Canvas Model", "Canvas" or "tool" that, without questioning the origin of the word and per simplification, will be used of the term "Canvas".

In this paper presented the main existing approaches Canvas, based answers for respondents, as shown in Table 1. In literature is possible can "Canvas" which can be grouped according to their functions:

- Project Management. The models are according to management of business practices of project and their strategies. Its main containers: project scope $[3,4,8]$, stakeholders[4,8,9], risks[4,8,9], costs[3,4,10], strategies[10], value aggregate[11], proposed value[12], customer relationships[3] and process $[4,9,12]$

- Inovation. The models found are directed to innovation products or services. Have containers: alternate solutions[13], costumer relationship[14], costs[13], strategies[14] and customer segmentation[13];

- Carrer. The model addresses the development of professional items. Its based in "Business Model Canvas" [3], but with focus in persons. Your containers are: "who will help", costs and "what I win" [15]

- Games. The models have objective to development digital games. It has containers: gamer actions, scenaries, target public, behaviours of personages, costs[5,16] and game mechanics[16].

Thus, the various Canvas can help professionals to prepare their projects, careers and new products or services.

\subsection{Profile of Team Members}

The characteristics of a staff member are called "profile"[18], which can be divided into[2]: (1) hard skill, corresponding to technical aspects; and (2) soft skill, referring to interpersonal and intrapersonal behavior. Another aspects may be considered as temperament, gender[19], expansiveness[20], team spirit and cooperation among team member[18].

The Profile must be directly linked to role played by each professional in the project that will actuate and can impact the performance of the team and the success of the project $[2,18]$

\section{Methodology}

The definition of the ontological and epistemological guidelines helps to understand the assumptions and analysis of the items that make up the search[21]. 
Table 1. Canvas Model

\begin{tabular}{|c|c|c|}
\hline Canvas & Description & Authors \\
\hline $\begin{array}{l}\text { Business Model } \\
\text { Canvas (BMC) }\end{array}$ & It is the creation of a business model & $\begin{array}{l}\text { Osterwalder and } \\
\text { Pigneur[3] }\end{array}$ \\
\hline $\begin{array}{l}\text { Project Model } \\
\text { Canvas (PMC) }\end{array}$ & $\begin{array}{c}\text { Prioritize planning and control of project } \\
\text { execution, based on the Project Management } \\
\text { Body of Knowledge }\end{array}$ & $\begin{array}{l}\text { Finocchio } \\
\text { Júnior }[4]\end{array}$ \\
\hline $\begin{array}{c}\text { Value } \\
\text { Proposition } \\
\text { Canvas (VPC) }\end{array}$ & $\begin{array}{l}\text { Value creation and submission pf the proposal } \\
\text { to the client. It is an extension of BMC }\end{array}$ & $\begin{array}{c}\text { Osterwalder, } \\
\text { Pigneur and } \\
\text { BernardaSmith }[11]\end{array}$ \\
\hline $\begin{array}{l}\text { Kickoff Canvas } \\
\text { (KC) }\end{array}$ & $\begin{array}{c}\text { Presents the information for the project opening } \\
\text { meeting }\end{array}$ & Kalbach[8] \\
\hline $\begin{array}{l}\text { Business Model } \\
\text { You (BMY) }\end{array}$ & $\begin{array}{c}\text { It is directed to professional career. Based on } \\
\text { BMC }\end{array}$ & Osterwalder[15] \\
\hline $\begin{array}{c}\text { Game Model } \\
\text { Canvas (GMC) }\end{array}$ & Aspects of the development of digital games & Drecon[5] \\
\hline $\begin{array}{l}\text { Startup Canvas } \\
\qquad(\mathrm{SC})\end{array}$ & $\begin{array}{c}\text { It is similar to a business plan and has the main } \\
\text { items to business creation and customer } \\
\text { acquisition }\end{array}$ & Methodkit[14] \\
\hline $\begin{array}{l}\text { Lean Canvas } \\
\quad(\mathrm{LC})\end{array}$ & $\begin{array}{l}\text { It has focus to the startups which combines } \\
\text { product concepts and market to generate } \\
\text { innovation. The author suggests using the BMC } \\
\text { after completing this Canvas }\end{array}$ & LeanStack[13] \\
\hline $\begin{array}{l}\text { Process Model } \\
\text { Canvas (PrMC) }\end{array}$ & $\begin{array}{c}\text { The key activities within a project and presents } \\
\text { the link between strategic management and } \\
\text { operational }\end{array}$ & $\begin{array}{c}\text { Bijl and } \\
\text { Ruting[12] }\end{array}$ \\
\hline $\begin{array}{l}\text { Program Model } \\
\text { Canvas } \\
\text { (ProgMC) }\end{array}$ & $\begin{array}{c}\text { Designed to project managers and project } \\
\text { management offices (PMO) to assist the } \\
\text { development phase of definitions and planning } \\
\text { of the project sets. There is compliance with the } \\
\text { BMC and PMC }\end{array}$ & $\begin{array}{l}\text { Sales, Arrivabene } \\
\text { and Prudencio[9] }\end{array}$ \\
\hline $\begin{array}{l}\text { The Customer } \\
\text { Jouney Canvas } \\
\text { (CJC) }\end{array}$ & $\begin{array}{l}\text { It has aimed to map the different actions of } \\
\text { consumers of services }\end{array}$ & $\begin{array}{l}\text { Stickdorn and } \\
\text { Schneider[17] }\end{array}$ \\
\hline $\begin{array}{l}\text { Portfólio Model } \\
\text { Canvas (PtMC) }\end{array}$ & $\begin{array}{l}\text { Allows to inventory the organization's projects, } \\
\text { create their prioritizations according to the } \\
\text { strategic objectives and resource constraints. } \\
\text { There are adherence to PMC }\end{array}$ & Finocchio $\operatorname{Jr}[10]$ \\
\hline
\end{tabular}


Ontology was objective, where reality exists independent of the researcher's knowledge[22]. The epistemology is interpretativist when it assumes that the data collected by the researcher can be used to test hypothesis or theories earlier. It has qualitative approach[23].

The flow of processes performed in this study follows the following order:

(1) Sending electronic survey. Have been sent a semi-structured electronic questionnaire[24] in Google Forms environment (drive.google.com) to groups of IT managers of Yahoo Groups (www.yahoogroups.com) and to social networks like Facebook (www.facebook.com) and LinkedIn (www.linkedin. com);

(2) Filtering the replies. It was only considered the respondents who mentioned that already using a Canvas;

(3) Standardization of answers. The role mentioned were standardized according the their functions;

(4) Analysis of profiles. It conducted a qualitative analysis of the collected items, without the study of frequencies[25].

\subsection{Collect}

The electronic questionnaire was sent to the group of IT managers of Yahoo Groups (7,917 contacts), for facebook (666 contacts) and LikedIn (1,415 contacts) with profiles different, totaling 9,998 contacts.

There were 65 respondents. When removing the blank responses resulted in 63 valid. In this paper we considered the respondents indicated that they worked or work with some Canvas resulting 43 responses.

Regarding the respondents roles was identified: Project Manager, Professors, Researchers, IT Students, Software Developer and IT Analyst. In this research were those who acted as project managers, even taking office as "Project Manager", "Administrator Department", "Engineer", "Process Analyst", "Business Analyst" or "Senior Systems Analyst", labeled "Project Manager". Another functions ware maintained.

\subsection{Propositions}

This research considered the following propositions and justifications:

- Proposition 1: There are a pattern between function exercised a team member and the use of Canvas. The Canvas are targeted to specific types of professionals, as managers[3,4,8], innovator[14] and others;

- Proposition 2: Professionals use in their activities the Canvas following suggested by the creators. There are Canvas to be applied on sequence, such as BMC and VPM[3] or the PMC and PtMC[4]. 


\section{Analysis of the Result}

Considering the information from the questionnaires were collected by function showed: $67 \%$ of Project Managements, $12 \%$ of IT Analyst, $7 \%$ Professor, $7 \%$ IT Student, Software Developer $5 \%$ and $2 \%$ Researcher. The profile and analysis of the collected data, as shown in Table 2, are:

- Project Manager. Was identified that the PMC is used by $62 \%$ of respondents and $58 \%$ using the BMC. Only $38 \%$ use BMC and PMC together. Those who use only the BMC correspond to $21 \%$. All those using the PMC also use another tool. When used the BMC not used GMC, PrMC, PgMC and CJC. None of the respondents in this group use GMC;

- IT Analyst. 80\% used BMC. Those who used BMC also applies LC (40\%) and GMC (20\%). Respondents who used VPC and PrMC not used BMC. None used the PMC, KC, BMY, SC, PgMC, CJC e PtMC;

- Professor. All use the BMG. All use the BMG. It was possible to identify a group that used only the BMC (67\%) and another group (33\%) using various tools together as VPC and PMC. Professors belong to different educational institutions;

- IT Student. All Student IT used BMC and no other tool. The students are from different educational institutions.

- Software Developer. It was possible to identify that $50 \%$ used the GMC. The other $50 \%$ was used BMC. In all cases only a Canvas was used;

- Researchers. All said they use only BMG. There was no use of any other Canvas.

\subsection{Discussion}

In relation a behavior of use with Canvas of Project Managers, the BMC conceptualizes the rules and business details to be created and the PMC has plans to implement the project. Is possible that the $\mathrm{BMC}$ and $\mathrm{PMC}$ are presents as the project management tools, but this union was explicit in only a small percentage (38\%). Despite the great use PMC (62\%) of managers, the number should be higher, because the PMC is directed to project management. The fact not use GMC may indicate that they do not know or that the project is not to development a digital game.

IT Analyst e Software Developer mentioned apply the BMC, but unaware the PMC. The BMC is related to management and not with the program creating or codification. This point the PMC was expected for these profiles, but which was not presented as fact. The GMC was mentioned by the Software Developer which could indicate that one game has been developed.

Professors have experience in BMC and some other Canvas. This may be the reason of Students have only applied the BMC in their daily lives.

Another point that was expected several types of Canvas was used by Researchers, but was mentioned only the BMC. Due to the role of seekers of knowledge, was expected a large number of tools used. In this way they could get the most out of this type of approach. 
Table 2. Profiles and Canvas

\begin{tabular}{cl}
\hline Profile & \multicolumn{1}{c}{ Identifications } \\
\hline & $-62 \%$ use the PMC \\
& $-58 \%$ used BMC \\
& $-38 \%$ used BMC+PMC \\
Project Manager & $-21 \%$ used PMC e outro Canvas \\
& - The BMC was not used with GMC, PrMC, PgMC and CJC \\
& $-0 \%$ used GMC \\
& $-80 \%$ use BMC \\
& $-40 \%$ used BMC and LC \\
Analyst IT & $-20 \%$ used BMC and GMC \\
& $-0 \%$ used PMC, KC, BMY, SC, PgMC, CJC and PtMC. \\
\hline \multirow{2}{*}{ Professor } & $-100 \%$ use BMC \\
& $-33 \%$ used in conjunction other tool \\
IT Student & $-100 \%$ used only BMC \\
\hline \multirow{2}{*}{ Software Developer } & - Just one Canvas used at a time \\
& - Canvas used BMC or GMC \\
\hline Research & $-100 \%$ used only BMC \\
\hline
\end{tabular}

Propositions created were compared with the results obtained during the research:

- Proposition 1: There are a pattern between function exercised a team member and the use of Canvas. It was possible to identify certain profiles determined using Canvas, such as Research, Professor and IT Student using BMC. Other profiles, as Project Manager, using more than two types;

- Proposition 2: Professionals use in their activities the Canvas following suggested by the creators. The research has shown the use of the Canvas did not follow the determination of creators. Is possible verify that the Project Manager uses the BMC and PMC that are of different authors and do not suggest a sequence in the application. Regarding IT Analyst were identified 10 types with different creators.

Regarding Proposition 1 research has shown that it is true, because it was possible to identify the Canvas according to the profile. Proposition 2 is false, because professionals do not follow the suggested sequence by the creators of the Canvas.

\section{Conclusion}

The canvas approach is a graphical alternative to the realization of planning. There are several types designed according to your goal as design, innovation, 
process or professional career. The profile of a member of team meets the technical and behavioral characteristics of the individual.

This paper presented 12 Canvas used by respondents, as the Business Model Canvas (BMC) and Project Model Canvas (PMC), the analysis of the type used by Project Manager, IT Analyst, Professors, Students, Software Developer and Researchers and showed interactions of profiles with Canvas.

The contribution to the academy is to present that there are relations between the use of the tools and professional profiles. However, the sequence of use idealized by the Canvas creators is not used by the professionals in practice. Regarding the practice, the results obtained can assist managers to choose the adequate Canvas Model, based on the profile of their team, indicating which tools are most popular and which can help to reduce the learning curve of the team members. The suggestion for future works is to study the barriers and challenges to the use of Canvas approach.

\section{Acknowledgements}

The authors thank CAPES for their support for the development of this research.

\section{References}

1. Sauser, B., Reilly, R., Shenhar, A.: Why Projects Fail? How Contingency Theory Can Provide New Insights-A Comparative Analysis of NASA's Mars Climate Orbiter Loss. International Journal of Project Management 27(7) (2009) 665-679

2. PMI: Project Management Body of Knowledge Guide. Four Campus Boulevard, Pensilvânia (2012)

3. Osterwalder, A., Pigneur, Y.: Business Model Generation. http:// businessmodelgeneration. com/canvas/bmc (2009)

4. Finocchio Júnior, J.: Project Model Canvas: Gerenciamento de Projetos sem Burocracia. Elsevier Brasil (2014)

5. Drecon: Game Model Canvas. www.drecon.com.br/GMC/Game_Model_Canvas_1_ 0_0.pdf (2015)

6. Neves, A.: Design Thinking Canvas. www.designthinkingcanvas.com.br (2014)

7. Frick, J., Ali, M.: Business Model Canvas as Tool for SME. In: Advances in Production Management Systems. Sustainable Production and Service Supply Chains. Springer (2013) 142-149

8. Wideman, M.: Project Kick-off Canvas. http://calleam.com/?p=1209 (2012)

9. Sales, L., Arrivabene, A., Prudencio, A.: Program Model Canvas. www. programmodelcanvas.com.br (2015)

10. Júnior, F.: Portfólio Model Canvas. http://www.pmcanvas.com.br (2015)

11. Osterwalder, A., Pigneur, Y., Bernarda, G., Smith, A.: Value Proposition Design. https://strategyzer.com/value-proposition-design (2014)

12. Bijl, M., Ruting, D.: Process Model Canvas. www.processmodelcanvas.net (2015) visited 2015-04-02.

13. LeanStack: Lean Canvas. www.leanstack.com (2015)

14. MethodKit: Startup Canvas. www.methodkit.com (2015)

15. Osterwalder, A.: Business Model You. www.businessmodelyou.com (2012) 
16. Jimémez, S.: Gamification Model Canvas. www.gameonlab.com/canvas (2015)

17. Stickdorn, M., Schneider, J.: The Customer Jouney Canvas. http:// filesthisisservicedesignthinKING.com/tisdt_cujoca_portugese.pdf (2015)

18. IPMA: ICB-IPMA Competence Baseline. Third version edn. International Project Management Association (2006)

19. Stawnicza, O.: Information and Communication Technologies-Creating Oneness in Globally Distributed IT Project Teams. Procedia Technology 16 (2014) 1057-1064

20. Stawnicza, O.: Information and Communication Technologies-Creating Oneness in Globally Distributed IT Project Teams. Procedia Technology 16 (2014) 1057-1064

21. Sarker, S., Xiao, X., Beaulieu, T.: Toward an Anatomy of "Successful" Qualitative Research Manuscripts in IS: A Critical Review and Some Recommendations. (2012)

22. Saccol, A.Z.: Um Retorno ao Básico: Compreendendo os Paradigmas de Pesquisa e sua Aplicação na Pesquisa em Administração. Revista de Administração da UFSM 2(2) (2009) 250-269

23. Walsham, G.: Doing Interpretive Research. European Journal of Information Systems 15(3) (2006) 320-330

24. Singh, K.: Quantitative Social Research Methods. Sage (2007)

25. Yin, R.K.: Case Study Research: Design and Methods. Sage publications (2013) 